\title{
$\beta$-globin haplotypes in normal and hemoglobinopathic individuals from Reconcavo Baiano, State of Bahia, Brazil
}

\author{
Wellington dos Santos Silva ${ }^{1}$, Maria de Nazaré Klautau-Guimarães ${ }^{2}$ and Cesar Koppe Grisolia ${ }^{2}$ \\ ${ }^{1}$ Faculdade Adventista da Bahia, Cachoeira, BA, Brazil. \\ ${ }^{2}$ Departamento de Genética e Morfologia, Instituto de Ciências Biológicas, Universidade de Brasília, \\ Brasilia, DF, Brazil.
}

\begin{abstract}
Five restriction site polymorphisms in the $\beta$-globin gene cluster (Hincll- $-5^{c} \varepsilon$, HindIII- ${ }^{G} \gamma$, HindIII- ${ }^{A} \gamma$, Hincll- $\psi \beta 1$ and Hincll-3 $\left.3^{\prime} \psi \beta 1\right)$ were analyzed in three populations $(n=114)$ from Reconcavo Baiano, State of Bahia, Brazil. The groups included two urban populations from the towns of Cachoeira and Maragojipe and one rural Afro-descendant population, known as the "quilombo community", from Cachoeira municipality. The number of haplotypes found in the populations ranged from 10 to 13 , which indicated higher diversity than in the parental populations. The haplotypes $2(+----), 3(---++), 4(-+-++)$ and $6(-++-+)$ on the $\beta^{A}$ chromosomes were the most common, and two haplotypes, $9(-++++)$ and $14(++--+)$, were found exclusively in the Maragojipe population. The other haplotypes $(1,5,9,11,12,13,14$ and 16) had lower frequencies. Restriction site analysis and the derived haplotypes indicated homogeneity among the populations. Thirty-two individuals with hemoglobinopathies (17 sickle cell disease, 12 $\mathrm{HbSC}$ disease and $3 \mathrm{HbCC}$ disease) were also analyzed. The haplotype frequencies of these patients differed significantly from those of the general population. In the sickle cell disease subgroup, the predominant haplotypes were BEN (Benin) and CAR (Central African Republic), with frequencies of $52.9 \%$ and $32.4 \%$, respectively. The high frequency of the BEN haplotype agreed with the historical origin of the afro-descendant population in the state of Bahia. However, this frequency differed from that of Salvador, the state capital, where the CAR and BEN haplotypes have similar frequencies, probably as a consequence of domestic slave trade and subsequent internal migrations to other regions of Brazil.
\end{abstract}

Key words: Afro-descendant, $\beta$-globin, haplotypes, hemoglobinopathies.

Received: August 24, 2009; Accepted: January 15, 2010.

\section{Introduction}

For more than 20 years haplotypes from the 5 ' region of the $\beta$-globin gene cluster have been used to study the origin and distribution of human populations (Wainscoat et al., 1986), as well as to trace the gene flux of variant hemoglobins $\mathrm{HbS}$ and $\mathrm{HbC}$ from Africa to other continents (Antonarakis et al., 1984; Pagnier et al., 1984).

The $\beta$-globin gene cluster system has proven to be very useful in studies of the evolutionary relationships of African, Eurasian and Pacific Islander populations. The results of these studies have supported an African origin for modern Homo sapiens and have helped to determine the major patterns of $\beta$-globin gene distribution. On a global scale, haplotypes $2(+----), 5(-+-++)$ and $6(-++-+)$ are the most prevalent in Eurasians whereas in Africans haplotype $3\left(--_{+}\right)$reaches a frequency $\geq 50 \%$ (Wainscoat $e t$

Send correspondence to Cesar Koppe Grisolia. Departamento de Genética e Morfologia, Instituto de Ciências Biológicas, Universidade de Brasília, 70910-900 Brasília, DF, Brazil. E-mail: grisolia@unb.br. al., 1986; Long et al., 1990; Chen et al., 1990). Guerreiro et al. (1992) and Bevilaqua et al. (1995) reported the distribution of these haplotypes among Brazilian Indians.

In Brazil, the first study of $\beta$-globin haplotypes among patients with sickle cell anemia found the three most common haplotypes linked to the $\beta^{\mathrm{S}}$ mutation from the African continent. Of 67 chromosomes, $49(66.2 \%)$ had the Central African Republic (CAR) haplotype, 17 (23.0\%) had the Benin (BEN) haplotype and one (1.3\%) had the Senegal (SEN) haplotype (Zago et al., 1992).

A subsequent study examined haplotypes of the $\beta^{S}$ cluster in 74 patients with sickle cell anemia from three representative towns in the regions with the highest number of afro-descendants in Brazil: Ribeirão Preto (State of São Paulo) in the southeast of Brazil, Salvador (State of Bahia) in the northeast and Belém (State of Pará) in the north (Figueiredo et al., 1994). The three most common African haplotypes were found in 138 chromosomes: the CAR haplotype predominated in the three regions (73.1\% in São Paulo, $54.8 \%$ in Bahia and $65.9 \%$ in Pará), followed by the 
BEN haplotype (25.4\% in São Paulo, 45.2\% in Bahia and $27.6 \%$ in Pará) and a small number of cases of the SEN haplotype in São Paulo (1.5\%) and Pará (6.9\%). Figueiredo et al. (1996) later reported frequencies of $61.8 \%$ and $34.7 \%$ for the CAR and BEN haplotypes, respectively, in the State of São Paulo.

Reconcavo Baiano, the focus of our study, is the region surrounding a large bay on the Atlantic Coast of Brazil, bordered to the north by the state capital Salvador (Figure 1). This region, which includes many historic and economically important cities, has had a long, close association with the state capital and with the history of the African slave trade. As a result, the Reconcavo Baiano has many Afro-derived Brazilian populations or "quilombos" that were originally founded by runaway slaves (Alencastro, 2000).

Although DNA polymorphisms in the 5' region of the $\beta$-globin cluster have been reported in populations from the state of Bahia (Figueiredo et al., 1994; Gonçalves et al., 2003; Adorno et al., 2004; Lyra et al., 2005), most of these studies have focused on the urban population of Salvador. There is no study of genetic variability in Afro-descendant populations from the Reconcavo Baiano region. Thus, the main goal of this study was to characterize the haplotypes resulting from DNA polymorphisms in the 5' region of the $\beta$-globin cluster and their distribution in populations from the Reconcavo Baiano. We also used these data to analyze intra- and interpopulational variability and genetic mixture in order to estimate the contribution of parental populations to the gene pool of the Reconcavo Baiano region.

\section{Material and Methods}

The sample for this study consisted of 114 unrelated male and female individuals from the towns of Cachoeira (S: $\left.12^{\circ} 37^{\prime} 04^{\prime \prime} \mathrm{W}: 38^{\circ} 57^{\prime} 21^{\prime \prime}\right)$ and Maragojipe (S: 12॰47' $\left.\mathrm{W}: 38^{\circ} 56^{\prime}\right)$. Of the 48 individuals living in central Maragojipe, 44 had HbAA, 1 had HbAC and 3 had HbAS electrophoretic profiles. The subjects from Cachoeira consisted of two groups: one of 34 individuals living in the town center (30 HbAA, $1 \mathrm{HbAC}$ and $3 \mathrm{HbAS})$ and the other of 32 in-

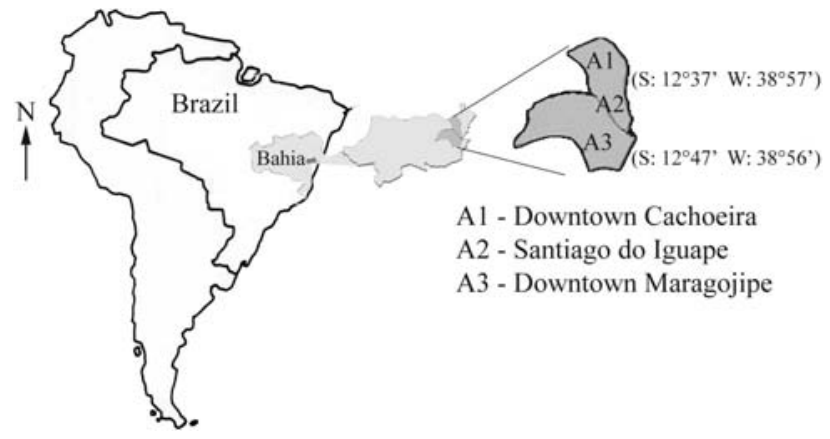

Figure 1 - Map showing the locations of the towns in the Reconcavo Baiano studied in this work. A1 - Downtown Cachoeira, A2 - Santiago do Iguape, A3 - Downtown Maragojipe. dividuals from the Afro-derived population of Santiago do Iguape (26 HbAA $1 \mathrm{HbAC}$ and $5 \mathrm{HbAS}$ ), a village located $44 \mathrm{~km}$ from central Cachoeira. These individuals were selected in community health programs run by the Faculdade Adventista da Bahia in partnership with the Fourth Regional Health Division of the State of Bahia and local health boards. The programs offer various health services such as vaccination, prenatal supervision, sex education, dental treatment and blood pressure and glycemia measurements.

In addition to these subjects, a further 22 individuals (male and female) bearing the sickle-cell trait (HbAS) and 32 unrelated patients with hemoglobinopathies (17 sicklecell disease, $12 \mathrm{HbSC}$ disease and $3 \mathrm{HbCC}$ disease) diagnosed in the Genetics Laboratory of the Department of Physiotherapy at the Faculdade Adventista were selected from other towns in the region.

Blood samples $(5 \mathrm{~mL})$ for electrophoretic and molecular analyses were collected in tubes containing EDTA $(0.03 \%)$ as anticoagulant. DNA from leukocytes in $100 \mu \mathrm{L}$ of venous blood was isolated using GFX Genomic Blood DNA purification kits (Amersham Lifesciences, Piscataway, NJ, USA). The presence of the variant hemoglobins $\mathrm{HbS}$ and $\mathrm{HbC}$ detected by the electrophoresis of hemoglobin in alkaline medium was confirmed by the polymerase chain reaction (PCR) followed by digestion with an appropriate restriction enzyme. The reaction protocol was a modified version of the Amplification Refractory Mutation System (ARMS) described by Attila et al. (2004).

DNA polymorphism was assessed by using a slightly modified version of the technique proposed by Sutton et al. (1989). Initially, DNA segments containing one of each of the polymorphic sites that we analyzed, namely, 1) HincII, in the 5' region of the $\varepsilon$ gene, 2) HindIII in IVS-2 of the ${ }^{\mathrm{G}} \gamma$ gene, 3) HindIII in IVS-2 of the ${ }^{\mathrm{A}} \gamma$ gene, 4) HincII in the $\psi \beta$ gene and 5) HincII in the 3 ' region of the $\psi \beta$ gene, were amplified by PCR. The amplifications were done in a final reaction volume of $25 \mu \mathrm{L}$ containing $25 \mathrm{pM}$ of each primer, $10 \mathrm{mM}$ Tris- $\mathrm{HCl}$ ( $\mathrm{pH} \mathrm{8.3),} 50 \mathrm{mM} \mathrm{KCl}, 1.5 \mathrm{mM} \mathrm{MgCl}_{2}$, $200 \mu \mathrm{M}$ of each deoxynucleotide triphosphate (dATP, dCTP, dGTP, dTTP) (Amersham Lifesciences), 1.0 U of Taq polymerase (Perkin Elmer Cetus Corporation, Norwalk, USA) and $100 \mathrm{ng}$ of genomic DNA. The reactions consisted of an initial step of DNA denaturation at $95^{\circ} \mathrm{C}$ for $2 \mathrm{~min}$, followed by 35 cycles of $1 \mathrm{~min}$ at $94^{\circ} \mathrm{C}$ for denaturation, $1 \mathrm{~min}$ at $54-57^{\circ} \mathrm{C}$ for primer pairing, $2 \mathrm{~min}$ at $72{ }^{\circ} \mathrm{C}$ for polymerization and a final step of $7 \mathrm{~min}$ at $72{ }^{\circ} \mathrm{C}$. The amplified products were digested with appropriate restriction enzymes and visualized in $1.5 \%$ agarose gels stained with ethidium bromide $(0.5 \mu \mathrm{g} / \mathrm{mL}) ; \phi X 174$ DNA digested with HaeIII was used as the size ladder.

Haplotypes and their respective frequencies were identified with Phase 2.1.1, a computer program that uses Bayesian algorithms (Stephens and Scheet, 2005). Inter- 
population genetic diversity was analyzed by the $\mathrm{G}_{\mathrm{ST}}$ calculation as provided by Fstat software based on equation 8.27 described by Nei (1987). This estimate was obtained in order to allow comparison with data in the literature since several recent reports have used $\mathrm{G}_{\mathrm{ST}}$ in their analyses of inter-populational diversity. Ethnic admixture was estimated by the gene identification method (Chakraborty, 1985) using the program ADMIX95 for a three-hybrid population. Representative allelic frequencies for African, European and native populations agreed with the mean frequencies reported in the current literature. This project was approved by the Ethics Committee of the University of Brasilia (protocol no. 021.0.000.012-04).

\section{Results}

Table 1 compares the distribution frequencies of the restriction sites in the $\beta$-globin gene complex of the three samples with those of the parental populations. The software Phase 2.1.1 identified 22 haplotypes in the $\beta$-globin cluster that had a frequency $\geq 1 \%$, based on a non-recombination method. Fourteen of these haplotypes were linked to $\beta^{\mathrm{A}}$ chromosomes, six to $\beta^{\mathrm{S}}$ chromosomes and two to $\beta^{\mathrm{C}}$ chromosomes.

The haplotypes linked to $\beta^{\mathrm{A}}$ chromosomes most commonly encountered in the samples from Maragojipe, $\mathrm{Ca}$ choeira and Iguape were 2, 3, 4, and 6 (Table 2). In addition, two haplotypes, 9 and 14, were specific to the Maragojipe population. Seven haplotypes identified in the three p opulations (haplotypes 1, 2, 3, 4, 5, 6 and 16) were considered first order haplotypes that originated by point mutations or gene-conversion events; haplotype 2 is likely to have been the ancestral form. Haplotypes 9, 11, 12, 13 and 14 were considered second order haplotypes and may have originated from recombination among first order ha-

Table 1 - Frequencies of restriction sites in the $\beta$-globin gene complex and in the parental populations (African, Amerindian and European) of the samples studied.

\begin{tabular}{|c|c|c|c|c|c|}
\hline Population & $\begin{array}{c}\text { HincII } \\
\text { 5' }^{\prime}\end{array}$ & $\begin{array}{l}\text { HindIII } \\
I V S 2^{G} \gamma\end{array}$ & $\begin{array}{l}\text { HindIII } \\
I V S 2{ }^{A} \gamma\end{array}$ & $\begin{array}{c}\text { HincII } \\
\psi \beta 1 \\
\end{array}$ & $\begin{array}{l}\text { HincII } \\
3^{`} \psi \beta 1\end{array}$ \\
\hline Maragojipe & 0.325 & 0.436 & 0.26 & 0.156 & 0.66 \\
\hline Cachoeira & 0.317 & 0.323 & 0.088 & 0.10 & 0.633 \\
\hline Iguape & 0.217 & 0.453 & 0.196 & 0.018 & 0.672 \\
\hline African (center-South) ${ }^{*}$ & 0.108 & 0.463 & 0.079 & 0.158 & 0.931 \\
\hline European $^{*}$ & 0.618 & 0.379 & 0.15 & 0.222 & 0.359 \\
\hline Amerindian ${ }^{\#}$ & 0.81 & 0.18 & 0.13 & 0.04 & 0.15 \\
\hline
\end{tabular}

*Data from Wainscoat et al. (1986) and Long et al. (1990). "Data from Guerreiro et al. (1994) and Bevilaqua et al. (1995).

Table 2 - Frequencies of the haplotypes connected to the $\beta^{\mathrm{A}}$ chromosome in the samples studied and the parental populations.

\begin{tabular}{|c|c|c|c|c|c|c|}
\hline $\begin{array}{l}\text { Haplotypes* (number of } \\
\text { chromosomes) }\end{array}$ & Maragojipe (88) & Cachoeira (60) & Iguape (52) & African ${ }^{\#}(79)$ & European $^{\#}(258)$ & Amerindian $^{\S}$ (477) \\
\hline 1. ----- & 0.0795 & 0.1000 & 0.0577 & 0.0000 & 0.0000 & 0.0060 \\
\hline 2.+---- & 0.1591 & 0.2000 & 0.1346 & 0.063 & 0.609 & 0.843 \\
\hline 3. ----+ & 0.1477 & 0.2167 & 0.2692 & 0.532 & 0.019 & 0.0000 \\
\hline 4. -+--+ & 0.1364 & 0.1667 & 0.2308 & 0.152 & 0.0000 & 0.0060 \\
\hline 5. - +-++ & 0.0795 & 0.0500 & 0.0000 & 0.139 & 0.377 & 0.0060 \\
\hline 6. -++-+ & 0.1364 & 0.0833 & 0.1346 & 0.025 & 0.113 & 0.122 \\
\hline 9. -++++ & 0.0341 & 0.0000 & 0.0000 & 0.0000 & 0.0000 & 0.0120 \\
\hline 11. ---++ & 0.0455 & 0.0333 & 0.0192 & 0.0000 & 0.0000 & 0.0000 \\
\hline 12. ++--- & 0.0455 & 0.0000 & 0.0577 & 0.0000 & 0.0000 & 0.0000 \\
\hline 13. +---+ & 0.0227 & 0.1000 & 0.0192 & 0.038 & 0.0000 & 0.0000 \\
\hline 14. ++--+ & 0.0114 & 0.0000 & 0.0000 & 0.013 & 0.0000 & 0.0000 \\
\hline 16. -+--- & 0.0000 & 0.0333 & 0.0577 & 0.013 & 0.0000 & 0.0000 \\
\hline $18 .+-+--$ & 0.0682 & 0.0167 & 0.0000 & 0.0000 & 0.0000 & 0.0000 \\
\hline 19.--+-+ & 0.0341 & 0.0000 & 0.0192 & 0.0000 & 0.0000 & 0.0000 \\
\hline
\end{tabular}

*Haplotypes 1 to 16 numbered according to Long et al. (1990) and haplotypes 18 and 19 according to Shimizu et al. (1992, 2001) and VillalobosArambula et al. (1997). "Data from Long et al. (1990) and Chen et al. (1990). ${ }^{\S}$ Data from Guerreiro et al. (1992). 
plotypes, as suggested in a scheme proposed by Long et al. (1990) and Chen et al. (1990).

The haplotype diversity indices obtained for the Maragojipe, Cachoeira and Iguape populations were 0.899, 0.870 and 0.835 , respectively. The variability for the haplotype diversity indices (Hs and $\mathrm{Ht}$ ) and the gene differentiation coefficients (Gst and Gst') for the populations from Reconcavo Baiano and other ethnic groups are shown in Table 3.

The extent of ethnic racial admixture was assessed by considering the three populations as a single sample. A three-hybrid population model was used to estimate the percentages for each parental population and yielded the following results: $80.4 \%$ African, $10.8 \%$ European and $8.8 \%$ native Amerindian, with a significant coefficient for multiple correlation $\left(\mathrm{R}^{2}=0.99\right)$.

Table 4 shows the haplotype distribution among hemoglobinopathic patients. BEN (Benin - Central West Africa) and CAR (Central African Republic) were the dominant haplotypes in $\beta^{\mathrm{S}}$ chromosomes, with frequencies of $52.9 \%$ and $32.4 \%$, respectively, in the sickle cell disease group; types I and II were the dominant haplotypes in $\beta^{\mathrm{C}}$ chromosomes, with frequencies of $55.5 \%$ and $44.5 \%$, respectively. Table 5 shows the frequencies for the $\beta^{\mathrm{S}}$ haplotypes in some Brazilian populations compared to those found in populations from the Reconcavo Baiano region. The frequency of the BEN haplotype was greater in the states of Bahia and Ceará, while in the other states the CAR haplotype was more frequent. The presence of the type-I haplotype (-+ - +) in $\beta^{\mathrm{C}}$ chromosomes agreed with historical data ascribing the origin of this haplotype to Central and West Africa, a region from which large numbers of slaves came to Brazil, especially to northeastern Brazil. However, the frequency of the type II haplotype in the Reconcavo Baiano region was higher than in African populations (Boehm et al., 1985; Talacki et al., 1990).

\section{Discussion}

Analysis of the distribution frequencies of the restriction sites showed that the frequencies for the HincII $5^{\prime} \varepsilon$ site ( 0.217 to 0.325$)$ were intermediate between those of the African population (0.108) and those of the European (0.618)
Table 4 - Haplotype distributions for $\beta^{\mathrm{S}}$ and $\beta^{\mathrm{C}}$ chromosomes in the three groups of hemoglobinopathic patients from the Reconcavo Baiano.

\begin{tabular}{lcccc}
\hline Haplotypes & $\begin{array}{c}\text { Patients } \\
\text { HbSS }\end{array}$ & $\begin{array}{c}\text { Patients } \\
\text { HbSC }\end{array}$ & $\begin{array}{c}\text { Patients } \\
\text { HbCC }\end{array}$ & Total \\
\hline$\beta^{\text {S }}$ chromosome & & & & \\
BEN & 18 & 6 & - & 24 \\
CAR & 11 & 4 & - & 15 \\
CAM & 1 & 0 & - & 1 \\
Atypical & 4 & 2 & - & 6 \\
Total & 34 & 12 & - & 46 \\
$\beta^{\mathrm{C}}$ chromosome & & & & \\
Type I & - & 9 & 1 & 10 \\
Type II & - & 3 & 5 & 8 \\
Total & - & 12 & 6 & 18 \\
\hline
\end{tabular}

and Amerindian (0.81) populations (Table 1). For the HindIII IVS2 ${ }^{\mathrm{G}} \gamma$ site, the frequencies of the samples from Maragojipe (0.436) and Iguape (0.453) were closer to those of the African population (0.463), whereas the Cachoeira sample had a lower frequency (0.323). Maragojipe (0.260) and Iguape (0.196) showed the highest frequencies for the HindIII IVS2 ${ }^{\mathrm{A}} \gamma$ restriction site, and the frequency for Cachoeira (0.088) was similar to that of the African population (0.079). The frequency of the HincII $\psi \beta 1$ site in the Iguape sample (0.018) was closer to the Amerindian population (0.04). The latter data indicated only a distant relationship (based on frequency) with the Maragojipe (0.156) and Cachoeira (0.100) populations, which were closer to the African population (0.158). The HincII 3' $\psi \beta 1$ site had the lowest variability among restriction sites in the three samples ( 0.633 and 0.672 ), with values between those of the European (0.359) and African (0.931) populations.

Fourteen haplotypes identified in the three populations accounted for $43.7 \%$ of the 32 possible haplotypes. This linkage-disequilibrium resulted from the proximity among restriction sites in a region of $\sim 32 \mathrm{~kb}$ where the overall recombination rate was estimated at $0.0017 \%$ (Chakravarti et al., 1984; Wood et al., 2005). Recombination of the most common haplotypes allowed for the existence of two atypical haplotypes.

Table 3 - Haplotype diversity for the $\beta$-globin cluster in populations from the Reconcavo Baiano area and parental populations.

\begin{tabular}{lcccccc}
\hline Population & Number of subpopulations & $\mathrm{Hs}$ & $\mathrm{Ht}$ & $\mathrm{Dst}$ & Gst & Gst' \\
\hline Reconcavo Baiano $^{\text {African }}{ }^{*}$ & 3 & 0.868 & 0.872 & 0.004 & 0.004 & 0.006 \\
European $^{*}$ & 6 & 0.650 & 0.710 & 0.060 & 0.085 & 0.100 \\
Amerindian $^{\#}$ & 5 & 0.590 & 0.820 & 0.030 & 0.280 & 0.060 \\
\hline
\end{tabular}

$\mathrm{Hs}$, average heterozygosity within populations; Ht, average heterozygosity for the entire population; Dst, interpopulational genetic variation; Gst, coefficient of gene differentiation; Gst', coefficient of gene differentiation, considering the number of populations examined. *Data from Long et al. (1990).

"Data from Mousinho-Ribeiro et al. (2003). 
Table 5 - Frequency distribution (\%) for the $\beta^{\mathrm{S}}$ haplotypes in the Reconcavo Baiano area and other Brazilian populations.

\begin{tabular}{|c|c|c|c|c|c|c|c|}
\hline \multirow[t]{2}{*}{ Population } & \multirow[t]{2}{*}{$\mathrm{N}$} & \multicolumn{6}{|c|}{ Haplotypes } \\
\hline & & CAR & BEN & SEN & CAM & ARAB & Atypical \\
\hline Reconcavo Baiano & 34 & 32.5 & 52.9 & 0.0 & 2.9 & 0.0 & 11.8 \\
\hline Salvador $(\mathrm{BA})^{1}$ & 250 & 41.6 & 55.2 & 0.4 & 1.2 & 0.4 & 1.2 \\
\hline Ceará $^{2}$ & 44 & 31.8 & 43.2 & 2.3 & 0.0 & 0.0 & 22.7 \\
\hline Pernambuco $^{3}$ & 127 & 81.1 & 14.2 & 0.0 & 0.8 & 0.0 & 3.9 \\
\hline Belém $(\mathrm{PA})^{4}$ & 260 & 66.0 & 21.8 & 10.9 & 1.3 & 0.0 & 0.0 \\
\hline São Paulo/Campinas (SP) $)^{5}$ & 142 & 64.8 & 35.2 & 0.0 & 0.0 & 0.0 & 0.0 \\
\hline Ribeirão Preto (SP) ${ }^{6}$ & 67 & 73.1 & 25.4 & 1.5 & 0.0 & 0.0 & 0.0 \\
\hline Porto Alegre $(\mathrm{RS})^{7}$ & 49 & 79.6 & 18.4 & 2.0 & 0.0 & 0.0 & 0.0 \\
\hline
\end{tabular}

$\mathrm{N}=$ number of chromosomes. 1. Adorno et al. (2008), 2. Galiza Neto et al. (2005), 3. Bezerra et al. (2007), 4. Cardoso and Guerreiro (2006), 5. Gonçalves et al. (1994), 6. Figueiredo et al. (1994), 7. Wagner et al. (1996).

Table 2 compares the haplotype frequencies of the three populations studied with the parental populations. The frequencies of haplotype 2 in the three samples were much higher than in the African population (0.063), and also greater than for the European and Amerindian populations ( 0.609 and 0.843 , respectively). In contrast, the frequency of haplotype 3 in the three samples was, at the most, half of the frequency found in the African population (0.532). The frequencies for haplotype 4 in the Maragojipe (0.1364) and Cachoeira (0.1667) populations were similar to that in the African population (0.152), whereas the Iguape population had the highest frequency for this haplotype (0.2308).

Haplotypes 18 and 19 were first described in Japanese subjects by Shimizu et al. (1992). Haplotype 18 was also subsequently identified in a mixed-blood Mexican population (Villalobos-Arambula et al., 1997) and in Colombian Amerindians (Shimizu et al., 2001). This haplotype had frequencies of 0.0682 and 0.0167 in the Maragojipe and Cachoeira populations, respectively, and was not detected in the Iguape population. Haplotype 19 was found in the populations of Maragojipe (0.0341) and Iguape (0.0192). However, there is no evidence of these two haplotypes in African, European and Brazilian Amerindian populations (Mousinho-Ribeiro et al., 2003; Callegari-Jacques et al., 2007).

The low coefficient of gene differentiation (Gst) for the three populations from Reconcavo Baiano (0.004; Table 3) indicated that the quilombo population from Santiago do Iguape shared no genetic structure with the urban populations of Cachoeira and Maragojipe. interethnic admixture may be the most important factor in the higher variability observed among the populations from Reconcavo Baiano. The ethnic admixture observed here agreed with the morphological data reported elsewhere (Azevedo, 1980), and with the outcomes of autosomal microsatellites recorded in the Bananal community, a village that was started by runaway slaves near the city of Jequié in Bahia (Barbosa et al., 2006). Although the population of this com- munity has a marked African influence, interethnic contacts throughout the community's history have had a profound impact on its genetic makeup.

Studies of the $\beta^{\mathrm{S}}$ haplotypes among HbSS individuals in northern, northeastern and southern Brazil have indicated that the average frequency for the predominant CAR haplotype in the three regions $(65.9 \%)$ agrees with historical data showing that about $70 \%$ of the African slaves transported to Brazil were from Angola, the Congo and Mozambique (Zago et al., 1992; Figueiredo et al., 1994). Bezerra et al. (2007) found a higher frequency for the CAR haplotype (79.2\%) in Pernambuco state, while the opposite was observed for the BEN haplotype (15.1\%). Comparison of these results with those for other states in northeastern Brazil indicates that the African descendants in this region have a heterogeneous origin.

Two studies have examined HbSS individuals from Salvador: in one, 17 out of 80 patients had the CAR/CAR genotype (21.3\%) (Gonçalves et al., 2003), while in the other, eight out of 40 patients $(20.0 \%)$ had this genotype (Lyra et al., 2005). In contrast, the frequency of this genotype did not exceed $12.0 \%$ among individuals in Reconcavo Baiano. In a more recent study involving a larger sample of patients with sickle cell anemia in the city of Salvador, $14.4 \%$ had the CAR/CAR genotype (Adorno et al., 2008). This phenomenon can be explained by internal migrations of Afro-descendants from other Brazilian regions to the State capital. Cardoso and Guerreiro (2006) observed the same phenomenon when they studied haplotype distribution in HbSS individuals from Belém city, in northern Brazil; these authors also found a higher frequency for the CAR haplotype than reported in historical records.

The Cameroon (CAM) haplotype that we identified comes from the West African coast, especially Nigeria (Kulozik et al., 1986; Oner et al., 1992). Other studies have also identified this haplotype in northeastern Brazil (Adorno et al., 2004, 2008; Bezerra et al., 2007). Cardoso and Guerreiro (2006) described this haplotype when they ana- 
lyzed the population in Belém and attributed it to slave migrations from northeastern to northern Brazil.

The historian Pierre Verger stated that the NagôIoruba influence in the State of Bahia originated with slaves brought to that state from the Gulf of Benin region. In contrast, other Brazilian states received most of their slaves from the Congo and Angola, where the CAR haplotype dominates (Verger, 1968). In the late $16^{\text {th }}$ and early $17^{\text {th }}$ centuries, there was intense slave trade from harbors in Ghana and Nigeria in the Gulf of Benin to Salvador and Recife, with several Afro-Brazilian religions being based on religious practices from this region in West Africa, where the Ioruba group predominates (Klein, 2002). In the $19^{\text {th }}$ century, when slavery became illegal in Brazil, most of the slaves who were manumitted in Salvador came from West Africa (Nishida, 1993).

The frequencies of the type I and type II $\beta^{\mathrm{C}}$ haplotypes found in Reconcavo Baiano (55.50\% and $45.50 \%$, respectively) differ from those reported by Bezerra et al. (2007) for Pernambuco state where the frequency of the type I haplotype was $80.0 \%$, and those of the type II and type III haplotypes were $13.2 \%$ and $6.6 \%$, respectively. Thus, the results from Pernambuco more closely resemble those found in African populations.

The frequency of $45.5 \%$ for the type II haplotype (- - $-+)$ in $\beta^{\mathrm{C}}$ chromosomes was higher than in Africa, where it ranges from $8 \%$ to 23\% (Boehm et al., 1985; Talacki et al., 1990). One possible explanation for the increase in this haplotype could be a bottleneck or founding effect. In this scenario, individuals who formed the first population that settled the Reconcavo Baiano region probably differed in their frequencies of both $\beta^{\mathrm{C}}$ haplotypes when compared to the ancestral populations, and this could have led to an increase in the frequency of the type II $\beta^{\mathrm{C}}$ haplotype.

\section{Acknowledgments}

This work was supported by the Faculdade Adventista de Fisioterapia and Universidade de Brasília.

\section{References}

Adorno EV, Zanette A, Lyra I, Souza CC, Santos LF, Menezes JF, Dupuit MF, Almeida MNT, Reis MG and Gonçalves MS (2004) The $\beta$-globin gene cluster haplotypes in sickle cell anemia patients from northeast Brazil: A clinical and molecular view. Hemoglobin 28:267-271.

Adorno EV, Zanette A, Lyra I, Seixas MO, Reis MG and Gonçalves MS (2008) Clinical and molecular characteristics of sickle cell anemia in the northeast of Brazil. Genet Mol Biol 31:621-625.

Alencastro LF (2000) O Tratado dos Viventes: A Formação do Brasil no Atlântico Sul. Companhia das Letras, São Paulo, $525 \mathrm{pp}$.

Antonarakis SE, Boehm CD, Serjeant GR, Theisen CE, Dover GJ and Kazazian Jr HH (1984) Origin of the $\beta^{\mathrm{S}}$-globin gene in blacks: The contribution of recurrent mutation or gene conversion or both. Proc Natl Acad Sci USA 81:853-856.

Attila G, Yalin S, Tuli A, Yalin E and Aksoy K (2004) Prenatal diagnosis of sickle cell anemia in twin pregnancies and identification by VNTRs. Clin Chim Acta 350:137-142.

Azevedo E (1980) Subgroup studies of black admixture within a mixed population of Bahia, Brazil. Ann Hum Genet 44:5561.

Barbosa AAL, Sousa SMB, Abé-Sandes K, Alonso CA, Schneider V, Costa DCC, Cavalli IJ and Azevedo EES (2006) Microsatellite studies on an isolated population of African descent in the Brazilian state of Bahia. Genet Mol Biol 29:23-30.

Bevilaqua LR, Mattevi VS, Ewald GM, Salzano FM, Coimbra Jr CEA, Santos RV and Hutz MH (1995) Beta-globin gene cluster haplotype distribution in five Brazilian Indian tribes. Am J Phys Anthropol 98:395-401.

Bezerra MA, Santos MNN, Araújo AS, Gomes YM, Abath FGC and Bandeira FMGC (2007) Molecular variations linked to the grouping of $\beta$ - and $\gamma$-globin genes in neonatal patients with sickle cell disease in the state of Pernambuco, Brazil. Hemoglobin 31:83-88.

Boehm CD, Dowling CE, Antonarakis SE, Honig GR and Kazazian Jr HH (1985) Evidence supporting a single origin of the $\beta^{\mathrm{C}}$-globin gene in Blacks. Am J Hum Genet 37:771-777.

Callegari-Jacques SM, Grossetti SG, Kohlrausch FB, Salzano FM, Tsuneto LT, Petzl-Erler ML, Hill K, Hurtado AM and Hutz MH (2007) The $\beta$-globin gene cluster distribution revisited - Patterns in Native American populations. Am J Phys Anthropol 134:190-197.

Cardoso GL and Guerreiro JF (2006) African gene flow to North Brazil as revealed by HBBS gene haplotype analysis. Am J Hum Biol 18:93-98.

Chakraborty R (1985) Gene identity in racial hybrids and estimation of admixture rates In: Neel JV and Ahuja Y (eds) Genetic Microdifferentiation in Man and other Animals. Indian Anthropological Association, Delhi, pp 171-181.

Chakravarti A, Buetow K, Antonarakis SE, Waber PG, Boehm CD and Kazazian HH (1984) Nonuniform recombination within the human $\beta$-globin gene cluster. Am J Hum Gen 36:1239-1258.

Chen L, Easteal S, Board P and Kirk R (1990) Evolution of $\beta$-globin haplotypes in human populations. Mol Biol Evol 7:423437.

Figueiredo MS, Olympio Silva MCB, Guerreiro JF, Pante-Souza G, Pires ACR and Zago MA (1994) The heterogeneity of the $\beta^{S}$ cluster haplotypes in Brazil. Gene Geogr 8:7-12.

Figueiredo MS, Kerbauy J, Gonçalves MS, Arruda VR, Saad STO, Sonati MF, Stoming T and Costa FF (1996) Effect of $\alpha$-thalassemia and $\beta$-globin gene cluster haplotypes on the hematological and clinical features of sickle-cell anemia in Brazil. Am J Hematol 53:72-76.

Galiza Neto GC, Pitombeira MS, Vieira HF, Vieira ML and Chaves FDAB (2005) Analysis of $\beta^{\text {S }}$ globin gene haplotypes in Ceará, Brazil. J Bras Patol Med Lab 41:315-321.

Gonçalves MS, Nechtman JF, Figueiredo MS, Kerbauy J, Arruda VR, Sonati MF, Saad SOT, Costa FF and Stoming TA (1994) Sickle cell disease in a Brazilian population from São Paulo: A study of the $\beta^{\mathrm{S}}$ haplotypes. Hum Hered 44:322327. 
Gonçalves MS, Bonfim CC, Maciel E, Cerqueira I, Lyra I, Zanette A, Bomfim G, Adorno EV, Albuquerque AL, Pontes A, et al. (2003) $\beta^{\mathrm{S}}$ haplotypes in sickle cell anemia patients from Salvador, Bahia, Northeastern Brazil. Braz J Med Biol Res 36:1283-1288.

Guerreiro JF, Figueiredo MS, Santos SEB and Zago MA (1992) $\beta$-globin gene cluster haplotypes in Yanomama Indians from the Amazon region of Brazil. Hum Genet 89:629-631.

Guerreiro JF, Figueiredo MS and Zago MA (1994) $\beta$-globin gene cluster haplotypes of Amerindian populations from the Brazilian Amazon region. Hum Hered 44:142-149.

Klein HS (2002) As origens africanas dos escravos brasileiros. In: Pena SD (ed) Homo Brasilis: Aspectos Genéticos, Linguísticos, Históricos e Socioantropológicos do Povo Brasileiro. 2nd edition. Funpec Editora, Ribeirão Preto, pp 93-112.

Kulozik AE, Wainscoat JS, Serjeant GR, Kar BC, Al-Awamy B, Essan GJF, Falusi AG, Hague SK, Hilali AM, Kate S, et al. (1986) Geographical survey of $\beta$-globin gene haplotypes: Evidence for an independent Asian origin of the sickle cell mutation. Am J Hum Genet 39:239-244.

Long J, Chakravarti A, Boehm CD, Antonarakis SE and Kazazian $H$ (1990) Phylogeny of human $\beta$-globin haplotypes and its implications for recent human evolution. Am J Phys Anthropol 81:113-130.

Lyra IM, Gonçalves MS, Braga JAP, Gesteira MF, Carvalho MH, Saad STO and Costa FF (2005) Clinical, hematological and molecular characterization of sickle cell anemia pediatric patients from two different cities in Brazil. Cad Saúde Púb 21:1287-1290.

Mousinho-Ribeiro RC, Pante-de-Souza G and Santos EJM (2003) Genetic relationships among Native Americans based on $\beta$-globin gene cluster haplotype frequencies. Genet Mol Biol 26:229-234.

Nei M (1987) Molecular Evolutionary Genetics. Columbia University Press, New York, 512 pp.

Nishida M (1993) Manumission and ethnicity in urban slavery: Salvador, Brazil, 1808-1888. Hisp Am Hist Rev 73:361391.

Öner PD, Dimovski AJ, Olivieri NF, Schiliro G, Codrington JF, Fattoum S, Adekile AD, Öner R, Yuregir GT, Altay C, et al. (1992) $\beta^{S}$ haplotypes in various world populations. Hum Genet 89:99-104.

Pagnier J, Mears JG, Dunda-Belkhodja O, Schaefer-Rego KE, Beldjord C, Nagel RL and Labie D (1984) Evidence for the multicentric origin of the sickle cell hemoglobin gene in Africa. Proc Natl Acad Sci USA 81:1771-1773.

Shimizu K, Park KS, Harihara S and Enoki Y (1992) Relationships between $\% \mathrm{Hb}$ F or $\% \mathrm{G}$ gamma and the haplotypes in the $\beta$-globin gene cluster in the normal adult Japanese and Korean populations. Hum Hered 42:216-221.

Shimizu K, Hashimoto T, Harihara S, Tajima K, Sonoda S and Zaninovic V (2001) $\beta$-globin gene haplotype characteristics of Colombian Amerinds in South America. Hum Hered 51:54-63.

Stephens M and Scheet P (2005) Accounting for decay of linkage disequilibrium in haplotype inference and missing data imputation. Am J Hum Genet 76:449-462.

Sutton M, Bouhassira EE and Nagel RL (1989) Polymerase chain reaction amplification applied to the determination of $\beta$-like globin gene cluster haplotypes. Am J Hematol 32:66-69.

Talacki CA, Rappaport E, Schwartz E, Surrey S and Ballas SK (1990) $\beta$-globin gene cluster haplotypes in Hb C heterozygotes. Hemoglobin 14:229-240.

Verger P (1968) Flux et Reflux de la Traite des Nègres entre le Golfe de Benin et Baia de Todos os Santos. Mouton Press, Paris, 720 pp.

Villalobos-Arámbula AR, Casas-Castañeda RBM, Perea EGFJ, Thein SL and Ibarra B (1997) $\beta$-thalassemia and $\beta^{A}$ globin gene haplotypes in Mexican mestizos. Hum Genet 99:498500.

Wagner SC, Friedrish JR, Job F and Hutz MH (1996) Caracterização molecular da anemia falciforme em pacientes de Porto Alegre. Rev Bras Genet 19:244.

Wainscoat J, Hill AVS, Boyce AL, Flint J, Hernandez M, Thein SL, Old JM, Lynch JR, Falusi AG, Weatherall DJ, et al. (1986) Evolutionary relationships of human populations from analysis of nuclear DNA polymorphisms. Nature 319:491-493.

Wood ET, Stover DA, Slatkin M, Nachman MW and Hammer MF (2005) The $\beta$-globin recombinational hotspot reduces the effects of strong selection around $\mathrm{HbC}$, a recently arisen mutation providing resistance to malaria. Am J Hum Genet 77:637-642.

Zago MA, Figueiredo MS and Ogo SH (1992) Bantu $\beta^{\mathrm{S}}$ cluster haplotype predominates among Brazilian blacks. Am J Phys Anthropol 88:295-298.

\section{Internet Resources}

Phase 2.1.1, courtesy of the Department of Statistics of the University of Washington, http://www.stat.washington.edu/stephens/software.html.

ADMIX95: http://www.genetica.fmed.edu.uy/software.htm.

Associate Editor: Francisco Mauro Salzano

License information: This is an open-access article distributed under the terms of the Creative Commons Attribution License, which permits unrestricted use, distribution, and reproduction in any medium, provided the original work is properly cited. 